\title{
The research of Value Co-Creation in the perspective of marketing WeiDong Xi
}

Marketing major, A lecturer, Research direction: Service marketing, promotion, nonprofit marketing Dalian institute of technology, China

Keywords: Value Co-Creation, Marketing management, service marketing, relationship marketing

\begin{abstract}
At present, the development of value creates a lot of attention due to the change of marketing research methods. The value creation in marketing research is the development and expansion of service marketing, service leading logic, relationship marketing, and the value of public creation. The fusion research of value co-creating and marketing research deserves further discussion. This paper examines the value of value from the perspective of marketing. First, through the development of marketing, the development of value co-development; Then from the concept of value creation subject and value two aspects discuss the value creation in marketing.
\end{abstract}

\section{Introduction}

In traditional marketing research, the role of enterprises and consumers is clearly defined in the exchange process. Enterprises and consumers as buyers and sellers, The enterprise is the main production value, The consumer is the main body that USES and consumes value. But after the 1980s, In the study of industrial marketing, service marketing and relationship marketing carried out in Europe, Value is not provided to consumers unilaterally by the enterprise, but by the interaction between the subjects. The consumer is not only the recipient of value, but the creation of value creation through the interaction with the enterprise and the creation of value creation. The concept of value co-create is gradually brought forward by the change of the role of consumers in this marketing.

\section{Traditional marketing research}

Marketing was born in the United States in the late 19th century and early 20th century, As a branch of business practice and social sciences, it has developed so far.

2.1 The budding of marketing. The background of early marketing is characterized by the arrival of mass production in the United States, Add in place, processing plant, consumer everywhere 。 With the development of major American capital in the late 19th century, A number of large corporations and oligarchs, Causing overproduction to exceed market demand, And the overproduction issue further causes international sales competition.

In order to solve the problem of overproduction and overproduction, some oligarchs started to take price countermeasures. However, the price countermeasures have reduced the profits of enterprises and caused vicious competition among enterprises. We have to explore marketing strategies beyond price competition. Thus, early marketing as a new sales technology is expected by enterprises.

2.2 The systematization of marketing management. With the improvement of production technology, the production efficiency is rapidly increasing, But the increasingly sluggish economy has caused consumers' purchasing power to plummet and competition between businesses has intensified. In order to gain competitive advantage, enterprises have to make technological innovations and expand investment. To recoup investment, you need to capture a steady market share. Ensuring market share, The marketing campaign is not only as a sales area, but also in the field of production, including comprehensive management activities such as product planning and equipment investment planning. 
In this context, marketing is the basic idea of enterprise activities, and becomes the management marketing of the management foundation of the enterprise. Management marketing includes planning, organization, control and other marketing activities.

2.3 the concept of marketing mix. Marketing mix is the basic concept or model of marketing, which refers to the marketing variables that a series of marketing workers can influence and operate and the marketing strategy that is proposed and implemented. The four elements of combinatorial marketing are often called 4P: Product, Price, Place, Promotion, It is also the main elements that constitute the modern marketing management system。In addition, some scholars have advocated the addition of political and public relations on the basis of $4 p$ on the basis of $4 p$ in relation to external environment, Referred to as 6P.

On the other hand, there are scholars who come up with " $4 \mathrm{c}$ " from the buyer's perspective, Customer, Cost, Communication, convenience 。

3 Expansion in marketing. Since the 1990s, it has gradually been affected by ICT。 The marketing area begins with the expansion of consumer market to industrial market, non-profit organization market, service market and other fields. Further expansion into customer relationship marketing and relationship marketing.

Service marketing and relationship marketing focus on the interaction between enterprises and consumers. Traditional marketing is the main line of exchange, which is the core of consumers of value producers and buyers of value. Service marketing and relationship marketing are no longer just about putting consumers in a position of accepting and consuming value, The consumer becomes the production subject of value through the interaction with the enterprises in the production of value, The theory of value co-creating begins to be noticed.

3.1 service marketing. With the economic deindustrialisation of the 1970s, services played an increasingly important role in economic activity. The research of service marketing can be divided into north American and Nordic studies. Research in North America treats services as intangible products and businesses increase exchange value through marketing activities 。 And the Nordic school believes that the service is determined by the customer from the purchase to the consumption process, which is the use value, Enterprises promote the interaction between enterprises and consumers through marketing activities to improve the use value of the use process.

3.2 relationship marketing. Relationship marketing has developed as an extension of marketing. Since the 1980s, it has gradually been noticed.

Traditional marketing is based on a one-time transaction, and relationship marketing is based on repetitive transactions. Therefore, relationship marketing attaches importance to the sustainability or sustainable period of trading relationships. With the purpose of relationship sustainability and relationship building, There are four types of exchange relationships that take place between the transaction subjects, namely, alliance, partnership, exchange and cooperation.

3.3 service dominant logic. After 2000, the core concept of value co-creating service dominated logic was brought forward. The service leadership logic treats customers and other subjects as part of the value creation process. Therefore, customers should be treated as co-producers of value. However, the value creation in the service leading logic does not mean that the consumers in the relationship marketing participate in the product development or the service marketing of the Nordic school. That is to say, the manufacturer produces the product without producing value, but the consumer USES the product to start to create the value. The service leading logic emphasizes that value itself is subjective cognition in the process of customer use, which is called thinking value. In short, the value in the service leading logic is generated by the use and consumption process of the exchange, as the thought value is generated by the customer's own judgment.

\section{From the perspective of marketing, value co-create}

The word co-creation is widely used in various fields. The development and expansion of service marketing, service leading logic, and relationship marketing is what marketing research suggests. The interaction between different subjects of marketing is gradually being paid attention to, and 
then we will create a new application in marketing research. The application of value co-creating in marketing needs to clarify the application value of what subject.

4.1 the value co-creates the main body. The concept of value creation in marketing research is not the transfer of value from one party to the other, but the realization that value is created by the interaction between the subjects. The main value creation in the traditional value chain is the maker, and the consumers who use and consume the product or service are the recipients of the value. And the Nordic service marketing school puts forward that consumers are dynamic participants in the marketing process, thus changing the meaning of traditional value subjects. Since the 1990s, with the change of production technology, especially the innovation of ITC, the relationship and function of the enterprises and consumers of traditional marketing subjects have had a great impact. As is known to all, with the help of ITC technology, consumers and enterprises have formed a network of communication and communication, making the interaction between enterprises and consumers easy to realize. The consumer is no longer merely passive acceptance of value, but the desire to seek solutions to their own desires. In this context, consumers not only accept the information and values provided by the enterprises unilaterally, but are active partners, even the value creators of autonomy. Therefore, the subject of value creation in marketing research expands from enterprise to consumer.

4.2 meaning of value. The concept of value in marketing is different from different perspectives, which can be summarized as follows:

First, the value of traditional marketing has always focused on functional value. The core of functional value is the idea of tangible products in traditional marketing.

Second, value is one of the means of differentiation strategy. Firstly, the value is divided into the economic value of price attribute, the function value of product attribute, and the convenience value of service attribute. When considering differentiation strategy, enterprises generally adopt the transition from economic value to function value and convenience value. But in recent years, the market has shown the trend of returning from the function value, the convenience value to the economic value.

The strategic focus of the product standardization period in mass production times is focused on the production efficiency and the economic value of the products. Gradually, the function of the product itself began to be differentiated in order to meet diversified market demands and a small number of production times. Therefore, the function value was paid attention to.However, with the improvement of enterprise product development capacity, in the same kind of products, in order to give the product quality difference, the enterprise began to develop the convenience value of additional services, By providing additional services, they differ from competitors to establish and maintain competitive advantage in the market But with the rise of technology and productivity, the value of functionality and the value of convenience have been lost. The core of differentiation strategy is to return to economic value from function value and convenience value.

Thirdly, the concept of value in marketing focuses on function value, exchange value and use value. Functional value is attached to a tangible product during production. The function value is created and is exchanged in the past, that is, the consumer pays for the function value of the currency, With the exchange of money, functional values are exchanged for value.

Finally, the value that is exchanged is converted to use value in the consumption process, That is, using value means being created together with the ultimate consumer in the process of consumption. If functional value is at the production stage of matter, as the core of the product, the use value is the core of the post-use phase. To sum up, in the process of production and consumption, enterprises are the sponsors of value, tangible products and services are carriers of value, and consumers are co-creators of value. The concept of value co-creating is mainly to explore the function value and use value. Functional value is related to the value of consumers, which is to make full use of consumers' knowledge and ideas by making consumers actively participate in the development process of products. The use value is related to the consumers' subjective perception and judgment of the thought value through consumption. 
To sum up, value creation and value creation are compared, as shown in table 1, The value of traditional marketing, the enterprise is the production subject, through the exchange of the market unilaterally transferred to the consumer. But with the development of diversified marketing, the concept of value co-creating has been widely used. The value of value creation is created by enterprises and consumers. The enterprise is the support of value creation. Consumers are the main creators of value.

Table 1 value and value co-create

\begin{tabular}{|l|l|l|}
\hline & Value creation & Value Co-Creation \\
\hline $\begin{array}{l}\text { Value creation } \\
\text { subject }\end{array}$ & enterprise & Enterprises and consumers \\
\hline Meaning of value & $\begin{array}{l}\text { Functional } \\
\text { value/exchange value }\end{array}$ & $\begin{array}{l}\text { Functional value, use value/thought } \\
\text { value, experience value }\end{array}$ \\
\hline Carrier of value & product & Products and services \\
\hline Market action & $\begin{array}{l}\text { A place of exchange } \\
\text { of value }\end{array}$ & $\begin{array}{l}\text { The place where the body interacts } \\
\text { with each other }\end{array}$ \\
\hline The academic basis & Traditional marketing & $\begin{array}{l}\text { Service marketing, relationship } \\
\text { marketing, service leading logic }\end{array}$ \\
\hline
\end{tabular}

\section{Conclusion}

This article has combed and discussed the development of marketing research from the perspective of value co-creating. Value creation is based on the interaction between the enterprise and consumers of the marketing entity.

Market marketing has been developed and accumulated through academic and practical development, and its application scope has been extended to many fields. With the innovative development of ITC, many stakeholders, such as enterprises and consumers, have become the subject of marketing, forming a complex and diverse network. With the development and popularization of social media such as SNS, there is a diverse network of businesses, between businesses and consumers, between consumers, and among other stakeholders. These changes will revolutionize the role of marketing in the process of production and consumption. In this context, the application of value to the marketing research is more and more. In the future, the concept, theory and application of the value created in marketing are more systematized.

\section{Reference}

[1]Chai Lee Goi.(2009) “A Review of marketing mix:4ps or more?”,International Journal of Marketing Studies, Vol.1,No.1,pp2-15.

[2]Christoper,M.(2004) Relationship marketing:Creatting Stakeholder Value,ELSEVIER. 